\title{
Hyperinsulinaemia, dyslipaemia and cardiovascular risk in girls with a history of premature pubarche
}

\author{
L. Ibáñez ${ }^{1}$, N. Potau ${ }^{3}$, P. Chacon ${ }^{2}$, C. Pascual ${ }^{2}$, A. Carrascosa ${ }^{1}$ \\ ${ }^{1}$ Adolescent and Endocrine Unit, Hospital Universitari Materno-Infantil Vall d'Hebron, Barcelona, Spain \\ ${ }^{2}$ Department of Clinical Chemistry, Hospital Universitari General Vall d'Hebron, Barcelona, Spain \\ ${ }^{3}$ Hormonal Laboratory, Hospital Universitari Materno-Infantil Vall d'Hebron, Barcelona, Spain
}

\begin{abstract}
Summary Girls with a history of premature pubarche, i.e. appearance of pubic hair before 8 years of age, show hyperinsulinism in response to an oral glucose tolerance test. As hyperinsulinaemia has a major role in dyslipaemia, and is considered an independent risk factor for cardiovascular disease, we assessed the patterns of plasma insulin concentration after a standard oral glucose tolerance test as well as fasting serum lipid, lipoprotein, and sex hormone-binding globulin concentrations in girls $(n=81)$ with premature pubarche compared with girls $(n=55)$ matched with them for stage and bone age to ascertain their metabolic states to identify those potentially at risk for the development of premature cardiovascular disease. Mean serum insulin concentrations were higher in patients at all pubertal stages, and associated with elevated serum triglyceride, very low density cholesterol and very low density triglyceride concentrations ( $p$ value range 0.04 to $<0.0001$ ) but reduced sex hor-
\end{abstract}

mone-binding globulin. Premature pubarche patients also displayed higher low density to high density lipoprotein cholesterol ratios compared with control subjects $(p=0.004$ to 0.008$)$. In conclusion, hyperinsulinaemia, decreased sex hormone-binding globulin concentrations and an unfavourable lipid pattern are common features in premature pubarche girls supporting the contention that atherogenic abnormalities composing the metabolic syndrome could start in childhood. To determine the clinical sequelae of such clustering of metabolic deviations, girls who were identified need to be followed up for the potential development of premature cardiovascular disease. [Diabetologia (1998) 41: 1057-1063]

Keywords Premature pubarche, hyperinsulinism, hyperandrogenism, dyslipaemia, cardiovascular disease.
Prospective epidemiological studies suggest that hyperinsulinaemia, both fasting and postprandial, can be an independent risk factor for the development of cardiovascular disease in non-diabetic subjects $[1,2]$. Hyperinsulinaemia or insulin resistance or both have been hypothesized to have a major role in dyslipa-

Received: 27 January 1998 and in final revised form: 11 May 1998

Corresponding author: L. Ibáñez, MD., Adolescent and Endocrine Unit, Hospital Universitari Materno-Infantil Vall d'Hebron, P0 Vall d'Hebron 119-129, 08035 Barcelona, Spain Abbreviations: Lp(a), Lipoprotein (a); SHBG, sex hormonebinding globulin; MSG, mean serum glucose; MSI, mean serum insulin; IRG, insulin response to glucose; $\mathrm{M}$, glucose uptake rate in peripheral tissues; SI, sensitivity to insulin. emia in subjects with both normal and impaired glucose tolerance [3-5]. Hyperinsulinaemia appears to enhance hepatic VLDL synthesis [6, 7] and thus could directly contribute to the increased triglyceride and LDL cholesterol values found in these subjects $[6,7]$.

The cluster of highly atherogenic metabolic abnormalities of syndrome X (hyperinsulinaemia, glucose intolerance, increased VLDL and triglycerides, decreased HDL cholesterol, and hypertension) are likely to be secondary to the basic abnormality of insulin resistance [3, 4, 6-12] and recent clinical studies in children have provided evidence that the genesis of an atherogenic pattern of risk factors could start in childhood $[13,14]$.

High concentrations of lipoprotein (a) Lp(a), an unusual lipoprotein defined by the presence of the 
Table 1. Clinical characteristics of patients and control subjects

\begin{tabular}{|c|c|c|c|c|c|c|c|c|c|c|}
\hline \multirow{2}{*}{$\begin{array}{l}\text { Tanner } \\
\text { breast stage }\end{array}$} & \multirow[t]{2}{*}{$n$} & \multirow{2}{*}{$\begin{array}{l}\text { CA } \\
\text { (year) }\end{array}$} & \multirow{2}{*}{$\begin{array}{l}\text { BA } \\
\text { (year) }\end{array}$} & \multirow{2}{*}{$\begin{array}{l}\text { BMI } \\
\left(\mathrm{Kg} / \mathrm{m}^{2}\right)\end{array}$} & \multirow{2}{*}{$\begin{array}{l}\text { systolic BP } \\
(\mathrm{mm} \mathrm{Hg})\end{array}$} & \multirow{2}{*}{$\begin{array}{l}\text { diastolic BP } \\
(\mathrm{mm} \mathrm{Hg})\end{array}$} & \multicolumn{4}{|c|}{ ACTH test at premature pubarche diagnosis ${ }^{\mathrm{a}}$} \\
\hline & & & & & & & $\begin{array}{l}\text { basal } \\
17-\mathrm{OHP} \\
(\mathrm{mmol} / \mathrm{l})\end{array}$ & $\begin{array}{l}\text { peak } \\
17-\mathrm{OHP} \\
(\mathrm{nmol} / \mathrm{l})\end{array}$ & $\begin{array}{l}\text { basal } \\
\Delta^{4}-\mathrm{A} \\
(\mathrm{nmol} / \mathrm{l})\end{array}$ & $\begin{array}{l}\text { basal } \\
\text { DHEAS } \\
(\mu \mathrm{mol} / \mathrm{l})\end{array}$ \\
\hline \multicolumn{11}{|l|}{$\mathrm{B} 1$} \\
\hline PP & 21 & $7.5 \pm 0.2$ & $8.6 \pm 0.2$ & $18.8 \pm 0.6$ & $104 \pm 2$ & $65 \pm 2$ & $1.9 \pm 0.3$ & $6.5 \pm 0.8$ & $4.4 \pm 0.5$ & $3.4 \pm 0.2$ \\
\hline $\mathrm{C}$ & 14 & $8.5 \pm 0.3$ & $7.8 \pm 0.3$ & $17.0 \pm 0.4$ & $103 \pm 2$ & $64 \pm 1$ & - & - & - & - \\
\hline \multicolumn{11}{|l|}{ B2 } \\
\hline PP & 19 & $9.8 \pm 0.1$ & $11.5 \pm 0.3$ & $20.4 \pm 0.6$ & $107 \pm 1$ & $66 \pm 2$ & $1.7 \pm 0.2$ & $7.6 \pm 0.6$ & $5.2 \pm 0.5$ & $3.3 \pm 0.3$ \\
\hline $\mathrm{C}$ & 10 & $11.1 \pm 0.1$ & $11.4 \pm 0.1$ & $18.5 \pm 0.6$ & $106 \pm 2$ & $65 \pm 2$ & - & - & - & - \\
\hline \multicolumn{11}{|l|}{ B3 } \\
\hline PP & 21 & $11.1 \pm 0.1$ & $12.6 \pm 0.1$ & $20.3 \pm 0.7$ & $109 \pm 3$ & $67 \pm 1$ & $2.2 \pm 0.3$ & $8.7 \pm 0.8$ & $4.7 \pm 0.4$ & $3.4 \pm 0.2$ \\
\hline $\mathrm{C}$ & 13 & $12.1 \pm 0.3$ & $12.5 \pm 0.2$ & $18.8 \pm 0.7$ & $109 \pm 2$ & $67 \pm 2$ & - & - & - & - \\
\hline \multicolumn{11}{|l|}{ B5 } \\
\hline PP & 20 & $15.8 \pm 0.4$ & $15.4 \pm 0.1$ & $21.3 \pm 0.6$ & $115 \pm 2$ & $70 \pm 2$ & $2.9 \pm 0.6$ & $9.2 \pm 0.8$ & $5.0 \pm 0.5$ & $3.3 \pm 0.4$ \\
\hline $\mathrm{C}$ & 16 & $15.4 \pm 0.3$ & $15.0 \pm 0.1$ & $19.8 \pm 0.4$ & $113 \pm 2$ & $69 \pm 2$ & - & - & - & - \\
\hline
\end{tabular}

Values are the mean \pm SEM. B1-B5, Tanner breast stages I-V; $\mathrm{PP}$, premature pubarche; $\mathrm{C}$, control subjects; $\mathrm{CA}$, chronological age; BA, bone age; BMI, body mass index; BP, blood pressure; ACTH: adrenocorticotropin; 17-OHP, 17-hydroxyprogesterone; $\Delta^{4}-\mathrm{A}$, androstenedione; DHEAS, dehydroepiandrosterone-sulphate.

unique apolipoprotein, apo (a) [15], are an independent risk factor for premature ischaemic disease, even in the presence of normal concentrations of other lipid parameters [16]. $\mathrm{Lp}(\mathrm{a})$ concentrations are strongly determined genetically, depend on the size of the apo(a) allele, and generally show little variation within a given person [17].

Girls with a history of premature pubarche, defined as the early appearance of pubic hair before 8 years of age [18], have an increased incidence of ovarian hyperandrogenism in adolescence, and show more hyperinsulinism after an oral glucose tolerance test than normal girls matched with them for age and body mass index $[19,20]$. The hyperinsulinaemia is detectable before the onset of puberty, throughout all stages of pubertal development and is accompanied by decreased sex hormone-binding globulin (SHBG) values [21].

Hyperinsulinaemia or insulin resistance or both are common features in lean and obese women with polycystic ovary syndrome, a form of ovarian hyperandrogenism [22, 23]. They are usually associated with an atherogenic lipid profile, namely, increased triglyceride and LDL concentrations and decreased HDL concentrations [24-26]. The lipid disturbances seem to be more associated with the hyperinsulinaemia than with the degree of androgen excess [25].

Our study aimed to ascertain whether the hyperinsulinism usually present in premature pubarche girls is accompanied by an abnormal lipid and lipoprotein pattern, in order to identify a subset of young patients potentially at an increased risk for the development of premature cardiovascular disease.
${ }^{\mathrm{a}}$ Normal values for control prepubertal girls [mean \pm SEM, $(n=240)]$, basal $17-\mathrm{OHP}: 1.2 \pm 0.1 \mathrm{nmol} / 1$; peak $17-\mathrm{OHP}$ : $5.9 \pm 0.3 \mathrm{nmol} / \mathrm{l} ; \quad \Delta^{4}-\mathrm{A}: \quad 2.4 \pm 0.1 \mathrm{nmol} / \mathrm{l} ; \quad$ DHEAS: $0.97 \pm$ $0.35 \mu \mathrm{mol} / 1$

\section{Subjects and methods}

Study groups. We studied 81 premature pubarche girls (age range: $5.9-18$ years) and 53 pubertal control subjects matched for stage and bone age [27, 28] (age range: 7-18 years). Subjects were divided into four groups according to their Tanner stage of breast development [28]: prepubertal (B1), early pubertal (B2), midpubertal (B3) and postmenarcheal (B5). All girls in groups B1-B3 were premenarcheal. In all patients, premature pubarche was secondary to premature adrenarche, namely, they presented with elevated androstendione or dehydroepiandrosterone-sulphate concentrations or both at premature pubarche diagnosis [29]. None of the subjects had been studied previously and 37 (26 patients and 11 control subjects) were assessed longitudinally.

None of the subjects had acanthosis nigricans, thyroid dysfunction, Cushing syndrome, hyperprolactinaemia, late-onset congenital adrenal hyperplasia [30, 31], a family or personal history of diabetes mellitus, a family history of premature cardiovascular disease, or was receiving medications known to affect lipid metabolism. Body mass indexes, the weight $(\mathrm{kg})$ divided by height $\left(\mathrm{m}^{2}\right)$, were similar in patients and control subjects within the same pubertal stage and were within the normal range in all subjects [32].

All subjects were on similar and unrestricted diets during the study. The protocol was approved by the institutional review committee at our hospital. Informed consent from patients or from their parents was obtained, as well as assent from minors. The baseline clinical characteristics of all groups are depicted in Table 1.

Patterns of insulin secretion. After 3 days of a daily high carbohydrate diet $(300 \mathrm{~g})$ and an 10-h overnight fast, all subjects were given a standard $1.75 \mathrm{~g} / \mathrm{kg}$ body weight (maximum $75 \mathrm{~g}$ ) 2-h oral glucose tolerance test starting at 0800 hours. At 0,30 , 60 and 120 min after oral glucose was given blood was sampled for glucose and immunoreactive insulin measurements. The fasting insulin resistance index was calculated as the product of the fasting serum insulin $(\mu \mathrm{U} / \mathrm{ml})$ and the fasting serum glu- 
Table 2. Androgen indexes, SHBG values and insulin secretion patterns

\begin{tabular}{llllllllll}
\hline $\begin{array}{l}\text { Tanner } \\
\text { stage }\end{array}$ & $n$ & $\begin{array}{l}\text { SHBG } \\
(\mathrm{mmol} / \mathrm{l})\end{array}$ & FAI & FIRI & $\begin{array}{l}\text { MSG } \\
(\mathrm{mmol} / \mathrm{l})\end{array}$ & $\begin{array}{l}\text { MSI } \\
(\mathrm{mU} / \mathrm{l})\end{array}$ & $\begin{array}{l}\text { IRG } \\
(\mathrm{mU} / \mathrm{mmol})\end{array}$ & $\begin{array}{l}\mathrm{M} \\
\left(\mathrm{mg} / \mathrm{min}^{2}\right)\end{array}$ & $\begin{array}{l}\text { SI } \\
\left(\mathrm{mg} \cdot \mathrm{l}^{-2} \cdot \mathrm{mmol}^{-1} \cdot\right. \\
\left.\mathrm{mU}^{-1} \cdot \mathrm{min}^{1}\right)\end{array}$ \\
\hline B1 & & & & & & & & & \\
PP & 21 & $72.7 \pm 5.0^{\mathrm{a}}$ & $1.2 \pm 0.1$ & $1.7 \pm 0.2$ & $6.3 \pm 0.2$ & $43.2 \pm 0.8^{\mathrm{f}}$ & $5.2 \pm 0.7$ & $449.3 \pm 22.9^{\mathrm{j}}$ & $46.9 \pm 3.4$ \\
C & 14 & $102.3 \pm 8.4$ & $1.0 \pm 0.1$ & $1.3 \pm 0.1$ & $5.6 \pm 0.3$ & $31.3 \pm 3.1$ & $3.7 \pm 0.4$ & $362.6 \pm 25.8$ & $46.5 \pm 0.9$ \\
B2 & & & & & & & & & \\
PP & 19 & $52.2 \pm 5.2$ & $1.7 \pm 0.2$ & $2.5 \pm 0.3$ & $6.5 \pm 0.1$ & $65.7 \pm 7.5^{\mathrm{f}}$ & $8.2 \pm 1.0$ & $578.2 \pm 19.1^{\mathrm{f}}$ & $52.6 \pm 2.9$ \\
C & 10 & $58.1 \pm 7.1$ & $1.7 \pm 0.2$ & $2.0 \pm 0.3$ & $5.9 \pm 0.2$ & $44.7 \pm 1.5$ & $5.9 \pm 0.9$ & $516.3 \pm 19.3$ & $54.1 \pm 4.7$ \\
B3 & & & & & & & & & \\
PP & 21 & $53.9 \pm 5.0^{\mathrm{b}}$ & $2.0 \pm 0.2^{\mathrm{d}}$ & $2.3 \pm 0.3$ & $6.5 \pm 0.1$ & $63.8 \pm 6.3^{\mathrm{c}}$ & $8.1 \pm 0.7^{\mathrm{h}}$ & $595.4 \pm 11.2$ & $53.7 \pm 2.5^{\mathrm{b}}$ \\
C & 13 & $72.5 \pm 7.3$ & $1.2 \pm 0.1$ & $2.0 \pm 0.3$ & $5.8 \pm 0.2$ & $34.5 \pm 2.8$ & $5.0 \pm 0.7$ & $556.3 \pm 19.3$ & $63.4 \pm 3.6$ \\
B5 & & & & & & & & & \\
PP & 20 & $35.5 \pm 3.3^{\mathrm{c}}$ & $8.0 \pm 1.5^{\mathrm{e}}$ & $2.9 \pm 0.9$ & $6.0 \pm 0.2$ & $76.6 \pm 11.8^{\mathrm{g}}$ & $9.2 \pm 1.3^{\mathrm{i}}$ & $607.2 \pm 10.6$ & $56.9 \pm 3.7^{\mathrm{b}}$ \\
C & 16 & $73.3 \pm 5.1$ & $1.3 \pm 0.1$ & $1.8 \pm 0.1$ & $5.7 \pm 0.1$ & $39.9 \pm 3.9$ & $4.9 \pm 0.3$ & $609.3 \pm 5.6$ & $67.1 \pm 2.1$ \\
\hline
\end{tabular}

Values are mean \pm SEM. SHBG, sex hormone-binding globulin; FAI, free androgen index [testosterone $(\mathrm{nmol} / \mathrm{l}) \times 100 /$ SHBG (nmol/l)]; FIRI, fasting insulin resistance index; MBG, mean serum glucose; MSI, mean serum insulin; IRG, insulin

response to glucose; $\mathrm{M}$, glucose uptake rate in peripheral tissues; SI, sensitivity to insulin. ${ }^{\mathrm{a}} p=0.001 ;{ }^{\mathrm{b}} p=0.01$; ${ }^{\mathrm{c}} p<0.0001 ;{ }^{\mathrm{d}} p=0.005 ;{ }^{\mathrm{e}} p=0.0002 ;{ }^{\mathrm{f}} p=0.02 ;{ }^{\mathrm{g}} p=0.0004$; ${ }^{\mathrm{h}} p=0.004 ;{ }^{\mathrm{i}} p=0.003$ and ${ }^{\mathrm{j}} p=0.009$ vs control subjects

cose (nmol/l) divided by 25 [21]. All subjects had normal glucose tolerance according to the Expert Committee on the Diagnosis and Classification of Diabetes Mellitus criteria [33].

The areas under the curve for glucose [mean serum glucose (MSG)], and insulin [mean serum insulin (MSI)] were calculated according to the trapezoidal rule. The initial insulin response to glucose (IRG), the glucose uptake rate in peripheral tissues (M value) and the degree of peripheral sensitivity to insulin (SI) were estimated simultaneously during the oral glucose tolerance test as described previously [20, 21, 34]. Serum glucose was measured by the glucose oxidase method. Immunoreactive insulin was assayed by IMX (Abbott, Madrid, Spain). The mean intra- and interassay coefficients of variation were 4.7 and $7.2 \%$, respectively. Individual values within 2SD of that of the control group were considered as within the normal range.

Lipid and lipoprotein measurements. Serum lipids and lipoproteins were measured from the baseline blood samples during the oral glucose tolerance test and LDL was calculated by the Friedewald formula. Lipoprotein fractionation was done using ultracentrifugation with a Centrikon T-1035, rotor type TFT 45.6 ultracentrifuge (Kontron International, Zurich, Switzerland). Total HDL was isolated by selective precipitation with phosphotungstic acid-magnesium chloride and measured by the CHOD-PAP method [35]. Serum and lipoprotein cholesterol and triglycerides were measured using CHOD-PAP and GPO-PAP based methods, respectively in a Hitachi 917 autoanalyser (Boehringer Mannheim, Mannheim, Germany). The mean intra- and interassay coefficients of variation were 2.2 and $2.0 \%$, respectively. Apolipoproteins Apo A-I and Apo B were determined by kinetic nephelometry using specific antibodies (Boehring Nephelometer Analyser). Apo C-II, Apo CIII and Apo E were measured by radial immunodiffusion (Daichii, Tokyo, Japan). Serum Lp(a) was measured by an enzymatic immunoassay (Macra Lp(a), Terumo Medical Corporation, Elkton, Md., USA). The intra- and interassay coefficients of variation were 2.3 and $5.09 \%$, respectively.

Androgen measurements. Serum SHBG and total testosterone were measured from baseline blood samples; SHBG was determined by RIA using monoclonal anti-SHBG antibodies [34], and testosterone was measured using a commercially available
RIA kit (Diagnostic Products Corp., Los Angeles, Calif., USA) [20]. The free androgen index, equivalent to free testosterone was calculated according to the following formula: [testosterone $(\mathrm{nmol} / \mathrm{l}) \times 100 / \mathrm{SHBG}(\mathrm{nmol} / \mathrm{l})][21,34]$.

All samples were immediately centrifuged, and serum was separated and frozen at $-20^{\circ} \mathrm{C}$ until assayed.

Statistical analysis. Anthropometric data and hormonal results are expressed as the mean \pm SEM unless otherwise stated. The Mann-Whitney nonparametric test was used to compare lipid and hormonal values among independent groups. Correlations were examined by using the Spearman's correlation test. $P$ values less than 0.05 were considered significant.

\section{Results}

Clinical data (Table 1). Body mass indexes did not differ significantly between patients and control subjects within the same Tanner stage. Mean systolic and diastolic blood pressure values were similar in patients and control subjects and were within the normal range in all subjects.

Androgen indexes, SHBG values and patterns of insulin secretion (Table 2). Patients had lower SHBG concentrations at B1, B3 and B5 ( $p=0.001 ; p=0.01$ and $p<0.0001$, respectively), and higher free androgen indexes at B3 and B5 ( $p=0.005$ and $p=0.0002$, respectively) compared with control subjects.

The fasting insulin resistance index was similar in patients and control subjects within the same Tanner stage, although premature pubarche girls tended to show higher values.

Patients and control subjects showed similar MSG concentrations but those of MSI were higher in patients at all Tanner stages, as expected $(p=0.02$; $p=0.02 ; p<0.0001$ and $p=0.009$ for $\mathrm{B} 1, \mathrm{~B} 2, \mathrm{~B} 3$ and B5, respectively). Similarly, patients showed higher 
Table 3. Lipid and lipoprotein profile in patients and control subjects

\begin{tabular}{|c|c|c|c|c|c|c|c|c|c|c|c|c|}
\hline $\begin{array}{l}\text { Tanner } \\
\text { stage }\end{array}$ & $n$ & $\begin{array}{l}\mathrm{TG} \\
(\mathrm{mmol} / \mathrm{l})\end{array}$ & $\begin{array}{l}\mathrm{TC} \\
(\mathrm{mmol} / \mathrm{l})\end{array}$ & $\begin{array}{l}\mathrm{HDL} \\
(\mathrm{mmol} / \mathrm{l})\end{array}$ & $\begin{array}{l}\mathrm{LDL} \\
(\mathrm{mmol} / \mathrm{l})\end{array}$ & $\begin{array}{l}\text { VLDL-C } \\
(\mathrm{mmol} / \mathrm{l})\end{array}$ & $\begin{array}{l}\text { VLDL-TG } \\
(\mathrm{mmol} / \mathrm{l})\end{array}$ & $\begin{array}{l}\text { Apo A-I } \\
(\mathrm{g} / \mathrm{l})\end{array}$ & $\begin{array}{l}\text { Apo B } \\
(\mathrm{g} / \mathrm{l})\end{array}$ & $\begin{array}{l}\text { Apo C-II } \\
(\mathrm{g} / \mathrm{l})\end{array}$ & Apo C-III & Apo E \\
\hline \multicolumn{13}{|l|}{1} \\
\hline PP & 21 & $4 \pm 0.11^{\mathrm{a}}$ & $4.09 \pm 0.09$ & $74 \pm 0.09$ & $.00 \pm 0.15$ & $0.20 \pm 0.01^{\mathrm{f}}$ & $0.46 \pm 0.04^{\mathrm{h}}$ & $0.94 \pm 8.2$ & $0.72 \pm 0.03$ & $.03 \pm 0.02$ & $0.06 \pm 0.05$ & 0.02 \\
\hline 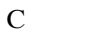 & 14 & $0.60 \pm 0.04$ & $4.08 \pm 0.04$ & 18 & 21 & $0.12 \pm$ & 0.31 & 1.22 & & .01 & .02 & .01 \\
\hline \multicolumn{13}{|l|}{2} \\
\hline $\mathrm{P}$ & 19 & $19 \pm 0.12^{b}$ & $4.37 \pm$ & $1^{\mathrm{e}}$ & 02 & $0.3=$ & 0.56 & $1.03=$ & 05 & 0.02 & 0.07 & 0.02 \\
\hline $\mathrm{C}$ & 10 & $0.71 \pm 0.03$ & $4.16 \pm$ & $1.90 \pm 0.06$ & 2 & & 0.23 & 1.03 & & 01 & .01 & 0.01 \\
\hline \multicolumn{13}{|l|}{3} \\
\hline PP & 21 & $15^{\mathrm{c}}$ & 4.18 & $1.48 \pm 0.08^{1}$ & $2.21=$ & $0.25 \pm 0.02^{\mathrm{c}}$ & $0.50 \pm 0.05^{\mathrm{i}}$ & 1.1 & $04^{\mathrm{e}}$ & 0.0 & 0.0 & 01 \\
\hline $\mathrm{C}$ & 13 & $0.71 \pm 0.03$ & $3.71 \pm$ & $1.47 \pm 0.07^{\mathrm{m}}$ & $1.89 \pm 0.08$ & $0.19 \pm$ & 0.14 & 0.96 & 2 & 0.0 & 0.07 & 0.01 \\
\hline \multicolumn{13}{|l|}{35} \\
\hline PP & 20 & 1.08 & $4.47 \pm 0.16^{\mathrm{d}}$ & 1.6 & $8^{\mathrm{a}}$ & $0.60 \pm 0.03^{\mathrm{f}}$ & 0.83 & 0.9 & & $0 .($ & 0.1 & 01 \\
\hline $\mathrm{C}$ & 16 & $0.69 \pm 0.05$ & $3.77 \pm 0.11$ & $1.61 \pm 0.13$ & $1.80 \pm 0.13$ & $0.46 \pm 0.01$ & $0.49 \pm 0.03^{\mathrm{n}}$ & $0.99 \pm 0.09$ & $0.67 \pm 0.03$ & $0.02 \pm 0.01$ & $0.06 \pm 0.02$ & $0.03 \pm 0.01$ \\
\hline \multicolumn{7}{|c|}{$\begin{array}{l}\text { Values are the mean } \pm \text { SEM. PP: premature pubarche; C: con- } \\
\text { trol subjects; TG: triglycerides; TC: total cholesterol; HDL, } \\
\text { LDL; VLDL-C: very low density lipoprotein cholesterol; } \\
\text { VLDL-TG: very low density lipoprotein triglyceride; Apo: } \\
\text { apolipoprotein. }\end{array}$} & \multicolumn{6}{|c|}{$\begin{array}{l}{ }^{\mathrm{a}} p=0.01 ; \quad{ }^{\mathrm{b}} p=0.006 ;{ }^{\mathrm{c}} p=0.04 ;{ }^{\mathrm{d}} p=0.004 ; \quad{ }^{\mathrm{e}} p=0.003 \\
{ }^{\mathrm{f}} p=0.0007 ;{ }^{\mathrm{g}} p=0.03 ;{ }^{\mathrm{h}} p=0.02 \text { and }^{\mathrm{i}} p<0.0001 \text { vs control sub- } \\
\text { jects. } \\
{ }^{\mathrm{j}} p<0.01 ;{ }^{\mathrm{k}} p=0.01 ;{ }^{1} p=0.03 ;{ }^{\mathrm{m}} p=0.02 ;{ }^{\mathrm{n}} p<0.0001 \text { vs prepu } \\
\text { bertal values }\end{array}$} \\
\hline
\end{tabular}

IRG at B3 and B5 ( $p=0.004$ and $p=0.003$, respectively), higher $\mathrm{M}$ values at B1 and at B2 ( $p=0.009$ and $p=0.02$, respectively), and lower SI indexes at $\mathrm{B} 3$ and $\mathrm{B} 5$ ( $p=0.01$ and $p=0.01$, respectively). All statistical differences persisted after adjustment for BMI.

Lipid and lipoprotein profile (Table 3). Serum triglyceride concentrations were higher in patients than in control subjects throughout puberty $(p=0.01$; $p=0.006 ; p=0.04$ and $p=0.01$ at $\mathrm{B} 1, \mathrm{~B} 2, \mathrm{~B} 3$ and $\mathrm{B} 5$, respectively). Patients showed higher total cholesterol concentrations at B3 and B5 ( $p=0.04$ and $p=0.004$, respectively), lower HDL concentrations at $\mathrm{B} 2(p=0.003)$, higher LDL concentrations at B5 $(p=0.01)$, and higher VLDL-cholesterol and VLDL-triglycerides at all pubertal stages ( $p$ values ranging from 0.02 to $<0.0001)$. As a group, patients showed higher triglyceride, total cholesterol, LDL, VLDL-cholesterol and VLDL-triglyceride concentrations than control subjects $(p<0.0001 ; p=0.001$; $p=0.01 ; p=0.02$ and $p=0.01$, respectively).

Apo A-I, Apo B and Apo C-II, Apo C-III and Apo $\mathrm{E}$ concentrations were similar in patients and control subjects at all pubertal stages tested except at B3, where premature pubarche girls showed higher Apo $\mathrm{B}$ and Apo C-II values ( $p=0.02$ and $p=0.03$, respectively).

The LDL to HDL ratio was significantly higher in patients than in control subjects throughout puberty, while the Apo A-I/Apo B and HDL to Lp(a) ratios showed no statistical differences between the two groups (data not shown). All statistical differences among groups persisted after adjustment for BMI.

The frequency distribution of $\mathrm{Lp}(\mathrm{a})$ concentrations showed that values less than $0.10 \mathrm{~g} / \mathrm{l}$ were most frequent in control subjects (79 vs $53 \%$ of patients). The percentage of subjects with $\mathrm{Lp}(\mathrm{a})$ values greater than $0.30 \mathrm{~g} / \mathrm{l}$ was similar in patients and control subjects (4 vs $5.1 \%$, respectively) (Fig. 1 ).

Correlations. Mean serum insulin concentrations correlated positively with those of triglyceride in all subjects $(r=0.51, p<0.0001)$ (Fig. 2$)$, and with the fasting insulin resistance index in patients only $(r=0.52$, $p=0.02$ ). Among others, significant correlations were found between MSI and LDL and between SI indexes and triglyceride concentrations in patients $(r=0.35, p=0.003$ and $r=-0.5, p=0.004$, respectively).

Serum SHBG correlated inversely with the MSI and with triglyceride concentrations in all subjects $(r=-0.52, p<0.0001$ and $r=0.37, p=0.0006$, respectively).

No correlations were found between the different lipid variables tested and the BMI, between the levels of lipids or insulin and blood pressure values, between Lp(a) levels and serum lipids, or between lipid and lipoprotein values and the adrenal androgen concentrations at premature pubarche diagnosis.

\section{Discussion}

Premature pubarche girls consistently have more hyperinsulinism, and higher triglyceride, VLDL-cholesterol and VLDL-triglyceride concentrations than normal girls both prepubertally and throughout puberty. The lipid profile is further characterized by higher LDL to HDL ratios, decreased HDL and increased LDL concentrations, and higher total cholesterol at most of the pubertal stages tested. Serum triglyceride concentrations were positively correlated with those of MSI and inversely with those of SHBG in all subjects. 


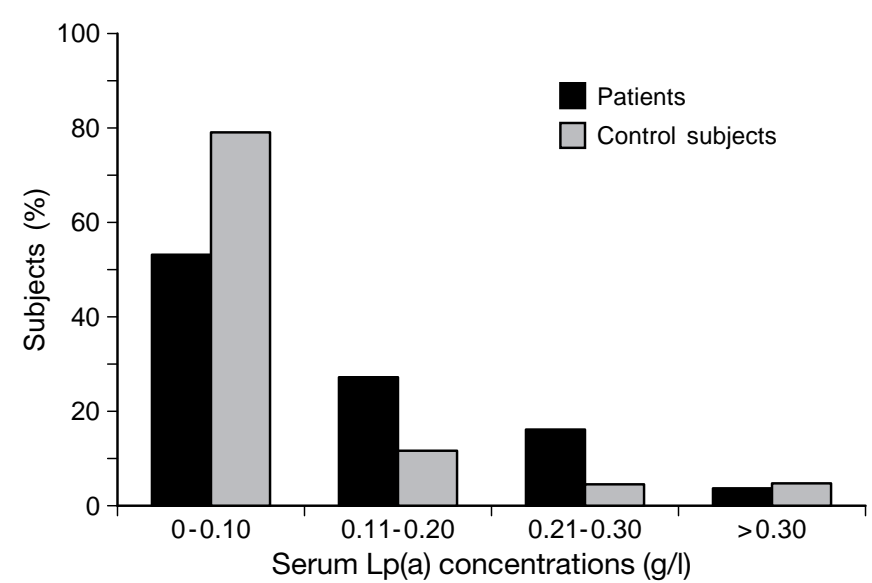

Fig. 1. Frequency distribution of lipoprotein (a) $[\mathrm{Lp}(\mathrm{a})]$ concentrations in patients and control subjects

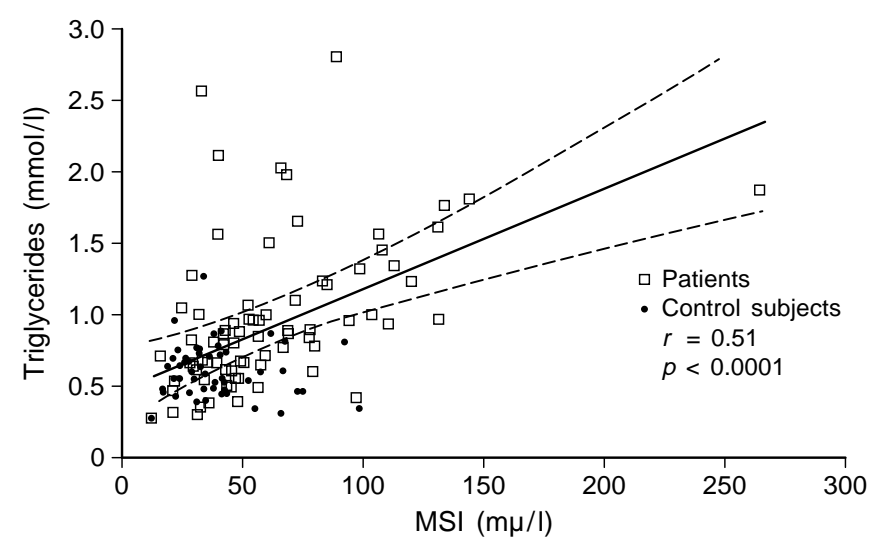

Fig. 2. Correlation between mean serum insulin (MSI) and triglyceride concentrations in all subjects

This distinct lipid profile in premature pubarche patients cannot be explained by differences in BMI compared with control subjects, but seems to be more related to hyperinsulinaemia and to the degree of androgen excess, as documented by the above correlations. This agrees with recent studies showing that per cent body fat is correlated with insulin sensitivity but has no relationship with plasma lipid concentrations [14]. Similarly, the male pattern of lipoprotein lipid concentrations usually present in women with androgen excess, cannot be explained solely by differences in body weight or composition; hyperandrogenaemia and insulin resistance seem to be the major contributors to their atherogenic lipid pattern [24-26, 36-38].

Blood pressure was normal in all patients and neither the systolic nor the diastolic values showed correlations with the serum concentrations of lipids or insulin tested. Hypertension and insulin resistance are frequently associated with an increased risk of cardiovascular disease [39]. Hypertension does not develop, however, in all insulin-resistant subjects, and not all hypertensive patients have insulin resistance and hy- perinsulinaemia [39]. Previous studies have shown significant correlations between diastolic blood pressure and insulin sensitivity as well as insulin concentrations in prepubertal children [14]. The method we used to estimate insulin sensitivity might account in part for the lack of a relation among these variables.

In population-based studies, hyperinsulinaemia has been associated with altered lipid concentrations, especially elevated triglycerides and total cholesterol and decreased HDL $[4,6]$. Serum triglycerides are correlated with insulin concentrations both in patients with primary hypertriglyceridaemia and in healthy subjects $[6,12,13]$. Increased fasting triglyceride is an independent risk factor for atherosclerosis [13] and values above $1.69 \mathrm{mmol} / \mathrm{l}$ have been associated with an increased risk of cardiovascular death [40]. In our group of premature pubarche girls, the most consistent finding was an increase in serum triglyceride, VLDL-cholesterol and VLDL-triglyceride concentrations at all pubertal stages. Forty per cent of patients showed triglyceride values above the mean $+2 \mathrm{SD}$ of those found in pubertal stage-matched control subjects, and in half of them the values were greater than $1.69 \mathrm{mmol} / \mathrm{l}$.

Increased LDL to HDL ratios were found in patients throughout puberty and were associated with elevated total cholesterol, Apo B and Apo-CII levels at midpuberty and higher total cholesterol concentrations postpubertally. High levels of LDL and of its carrier protein, apo B, and decreased HDL and Apo-AI concentrations have also been deemed independent risk factors for the development of premature cardiovascular disease [40].

The frequency distribution of $\mathrm{Lp}(\mathrm{a})$ concentrations showed that the per cent of subjects with $\mathrm{Lp}(\mathrm{a})$ values greater than $0.30 \mathrm{~g} / \mathrm{l}$, considered to contribute to a greater extent to atherogenesis, was similar in patients and control subjects. Serum Lp(a) track from childhood and little variation in its levels are observed after 5 years of age [41]. Interestingly, Lp(a) levels less than $0.10 \mathrm{~g} / \mathrm{l}$ were found most frequently in control subjects suggesting that the increased androgens in premature pubarche girls might exert a regulatory role on serum $\mathrm{Lp}(\mathrm{a})$ levels due to their capability to influence hepatic metabolism pathways of this glycoprotein [42].

Our results seem to support the contention that the cluster of risk factors for cardiovascular disease development already starts in childhood [12-14]. Therefore, pathophysiological connections between hyperinsulinaemia and dyslipaemia can be hypothesized. Insulin stimulates the proliferation of arteriolar smooth muscle cells, augments collagen synthesis in the vascular wall, increases the formation of lipid plaques and enhances the production of plasminogen activator inhibitor type I $[43,44]$. The increased insulin concentrations concurrent with the altered lipid profile might begin this process already in the prepuber- 
tal period [13, 14, 41]. The addition of decreased SHBG and increased insulin levels can subsequently favour the development of Type II diabetes mellitus, which conveys a further higher risk for cardiovascular disease in these patients [21, 45].

In conclusion, hyperinsulinaemia, increased serum triglyceride, VLDL-cholesterol, VLDL-triglyceride and LDL to HDL ratios are common features in premature pubarche girls from childhood, supporting the supposition that the cluster of highly atherogenic abnormalities of syndrome X can start in childhood. These findings emphasize the supposition that premature pubarche is not a benign condition and we recommend follow up of these patients through adulthood to ascertain whether they are potentially at risk for the development of premature cardiovascular disease.

Acknowledgements. This work was supported by funds from the Fundació d'Investigació Clinica of the Hospital MaternoInfantil Vall d'Hebron. We are indebted to Dr. Begoña Bermejo at the Epidemiology Department, Hospital Universitari Vall d'Hebron, Barcelona, for statistical analysis, and to Dr. Lluis Masana at the Unitat de Recerca de Lípids i Arteriosclerosi, Unitat d'Investigació de l'Hospital Sant Joan, Universitat Rovira i Virgili, Reus, Spain and Dr. Paul Saenger at the Department of Pediatrics, Albert Einstein College of Medicine/Montefiore Medical Center, Bronx, New York for reviewing the manuscript and for their helpful advice.

\section{References}

1. Després JP, Lamarche B, Mauriege P et al. (1996) Hyperinsulinemia as an independent risk factor for ischemic heart disease. N Engl J Med 334: 952-957

2. Reaven GM, Laws A (1994) Insulin resistance, compensatory hyperinsulinaemia, and coronary heart disease. Diabetologia 37: 948-952

3. Abbott WGH, Lillioja S, Young AA (1987) Relationships between plasma lipoprotein concentrations and insulin action in a obese hyperinsulinemic population. Diabetes 36 : 897-904

4. Laakso M, Sarlund H, Mykkanen L (1990) Insulin resistance is associated with lipid and lipoprotein abnormalities in subjects with varying degrees of glucose tolerance. Arteriosclerosis 10: 223-231

5. Garg A, Helderman JH, Koffler M, Ayuso R, Rosenstock J, Raskin P (1988) Relationships between lipoprotein levels and in vivo insulin action in normal young white men. Metabolism 37: 982-987

6. Orchard TJ, Becker DJ, Bates M, Kuller LH, Drash AL (1983) Plasma insulin and lipoprotein concentrations: an atherogenic association? Am J Epidemiol 118: 326-337

7. Stalder M, Pometta D, Suenram A (1981) Relationship between plasma insulin levels and high density lipoprotein cholesterol levels in healthy men. Diabetologia 21: 554-558

8. Després JP (1993) The insulin resistance-dyslipidemia syndrome: the most prevalent cause of coronary artery disease? Can Med Assoc J 148: 1339-1340

9. Ferrannini E, Haffner SM, Mitchell BD, Stern MP (1991) Hyperinsulinaemia: the key feature of a cardiovascular and metabolic syndrome. Diabetologia 34: 416-422
10. Haffner SM, Valdez RA, Hazuda HP, Mitchell BD, Morales PA, Stein M (1992) Prospective analysis of the insulin-resistance syndrome (syndrome X). Diabetes 41: 715-722

11. Laws A, Reaven GM (1992) Evidence for an independent relationship between insulin resistance and fasting plasma HDL-cholesterol, trygliceride and insulin concentrations. J Intern Med 231: 25-30

12. Zavaroni I, Bonora E, Pagliara M et al. (1989) Risk factors for coronary artery disease in healthy persons with hyperinsulinemia and normal glucose tolerance. N Engl J Med 320: 702-706

13. Rönnemaa T, Knip M, Lautala P et al. (1991) Serum insulin and other cardiovascular risk indicators in children, adolescents and young adults. Ann Med 23: 63-72

14. Arslanian S, Suprasongsin C (1996) Insulin sensitivity, lipids, and body composition in childhood: is "Syndrome X" present? J Clin Endocrinol Metab 81: 1058-1062

15. Utermann G (1989) The mysteries of lipoprotein (a). Science 246: 904-910

16. Sandkamp M, Funke H, Schulte H, Köhler E, Assmann G (1990) Lipoprotein (a) is an independent risk factor for myocardial infarction at a young age. Clin Chem 36/1: 20-23

17. Boerwinkle E, Leffert CC, Lin J, Lackner C, Chiesa G, Hobbs HH (1992) Apolipoprotein (a) gene accounts for greater than $90 \%$ of the variation in plasma lipoprotein (a) concentration. J Clin Invest 90: 52-60

18. Ibáñez L, Virdis R, Potau N, Zampolli M et al. (1992) Natural history of premature pubarche: an auxological study. J Clin Endocrinol Metab 74: 254-257

19. Ibáñez L, Potau N, Virdis R et al. (1993) Postpubertal outcome in girls diagnosed of premature pubarche during childhood: increased incidence of functional ovarian hyperandrogenism. J Clin Endocrinol Metab 76: 1599-1603

20. Ibáñez L, Potau N, Zampolli M et al. (1996) Hyperinsulinemia in postpubertal girls with a history of premature pubarche and functional ovarian hyperandrogenism. J Clin Endocrinol Metab 81: 1237-1243

21. Ibáñez L, Potau N, Zampolli M, Riqué S, Saenger P, Carrascosa A (1997) Hyperinsulinemia and decreased insulin-like growth factor binding protein-1 are common features in prepubertal and pubertal girls with a history of premature pubarche. J Clin Endocrinol Metab 82: 2283-2288

22. Ehrmann DA, Barnes RB, Rosenfield RL (1995) Polycystic ovary syndrome as a form of functional ovarian hyperandrogenism due to dysregulation of ovarian androgen secretion. Endocr Rev 16: 322-353

23. Dunaif A, Segal KR, Futterweit W, Dobrjansky A (1989) Profound peripheral insulin resistance, independent of obesity, in the polycystic ovary syndrome. Diabetes 38 : 1165-1174

24. Wild RA, Painter PC, Coulson PB, Carruth KB, Ranney GB (1985) Lipoprotein lipid concentrations and cardiovascular risk in women with polycystic ovary syndrome. J Clin Endocrinol Metab 61: 946-951

25. Wild RA, Alaupovic P, Parker IJ (1992) Lipid and lipoprotein abnormalities in hirsute women. 1. The association with insulin resistance. Am J Obstet Gynecol 166: 1191-1197

26. Robinson S, Henderson AD, Gelding SV et al. (1996) Dyslipidemia is associated with insulin resistance in women with polycystic ovaries. Clin Endocrinol (Oxf) 44: 277-284

27. Greulich WW, Pyle SI (1959) Radiographic atlas of skeletal development of the hand and wrist. 2nd edn. Standford University Press, Stanford, California 
28. Marshall WA, Tanner JM (1969) Variations in the pattern of pubertal changes in girls. Arch Dis Child 44: 291-303

29. Rosenfield RL, Rich BH, Lucky AW (1982) Adrenarche as a cause of benign pseudopuberty in boys. J Pediatr 101: 1005-1009

30. New MI, Lorenzen F, Lerner AJ et al. (1983) Genotyping steroid 21-hydroxylase deficiency: hormonal reference data. J Clin Endocrinol Metab 56: 3320-3325

31. Sakkal-Alkaddour H, Zhang L, Yang X et al. (1996) Studies of $3 \beta$-hydroxysteroid dehydrogenase genes in infants and children manifesting premature pubarche and increased adrenocorticotropin-stimulated $\Delta^{5}$-steroid levels. J Clin Endocrinol Metab 81: 3961-3965

32. Hernández M, Castellet J, Narvaiza JL et al. (1988) Curvas y tablas de crecimiento. Instituto de Investigaciones sobre crecimiento y desarrollo. In: Garsi (eds) Fundación F. Orbegozo, Madrid, Spain

33. The Expert Committe on the Diagnosis and Classification of Diabetes Mellitus (1997) Report of the Expert Committee on the Diagnosis and Classification of Diabetes Mellitus. Diabetes Care 20: 1183-1197

34. Ibáñez L, Potau N, Georgopoulos N, Prat N, Gussinyé M, Carrascosa A (1995) Growth hormone, insulin-like growth factor-I axis and insulin secretion in hyperandrogenic adolescents. Fertil Steril 64: 1113-1119

35. Assman G, Schiewr H, Schnitz G, Haegle D (1983) Quantification of high density lipoprotein cholesterol by precipitation with phosphotungstic acid- $\mathrm{Mg}-\mathrm{Cl}_{2}$. Clin Chem 29: 2026-2030

36. Haffner SM, Valdez RA (1995) Endogenous sex hormones: impact on lipids, lipoproteins, and insulin. Am J Med 98(1A):40S-47S
37. Nestler JE (1997) Role of hyperinsulinemia in the pathogenesis of the polycystic ovary syndrome, and its clinical implications. Semin Reprod Endocrinol 15(2):111-122

38. Dunaif A (1997) Insulin resistance and the polycystic ovary syndrome: mechanism and implications for pathogenesis. Endocr Rev 18: 774-800

39. Reaven GM, Lithell H, Landsberg L (1996) Hypertension and associated metabolic abnormalities - the role of insulin resistance and the sympathoadrenal system. N Engl J Med 334: 374-380

40. Wilcken DE, Wang XL, Greenwood J, Lynch J (1993) Lipoprotein (a) in children and apolipoproteins B and A-1 in children and coronary vascular events in their grandparents. J Pediatr 123: 519-526

41. Kostner GM, Czinner A, Pfeiffer KH, Bihari-Varga M (1991) Lipoprotein (a) concentrations as risk indicators for atherosclerosis. Arch Dis Child 66: 1054-1056

42. Berglund L, Carlström K, Stege R et al. (1996) Hormonal regulation of serum lipoprotein (a) levels: effects of parenteral administration of estrogen or testosterone in males. $\mathrm{J}$ Clin Endocrinol Metab 81: 2633-2637

43. De Fronzo RA (1992) Insulin resistance, hyperinsulinemia, and coronary artery disease: a complex metabolic web. J Cardiovasc Pharmacol 20 [Suppl 11]:S1-S16

44. Schneider D, Sobel B (1996) Synergistic augmentation of expression of PAI-1 induced by insulin, VLDL, and fatty acids. Coron Artery Dis 7: 813-817

45. Folsom AR, Szklo M, Stevens J, Liao F, Smith R, Eckfeldt JH (1997) A prospective study of coronary heart disease in relation to fasting insulin, glucose and diabetes. Diabetes Care 20: 935-942 